\title{
EFEK LESSON STUDY TERHADAP PENINGKATAN KOMPETENSI PEDAGOGIK CALON GURU
}

\author{
Swaditya Rizki \\ FKIP Universitas Muhammadiyah Metro \\ E-mail: swaditya.rizki@gmail.com
}

\begin{abstract}
The aims of this research was to know difference increasing especially ability in Plan and Do between lesson study-based learning and not(conventional) learning. Furthermore, the second aim was to know the effect of lesson study toward increasing of pedagogy competency and impact of prospective teachers in teaching. The methodology of this research was using descriptive qualitative with amount of prospective teachers is 13 , then the prospective teachers conducted Plan and Do respectively 3 times meeting using lesson study and conventional. The results showed that the effect was very positive where the learning process of Plan and Do using lesson study was better than conventional learning. Besides that, based on the observation and valuation showed that lesson study-based learning was better than conventional learning. The effect could also influence for students and prospective teacher positively.
\end{abstract}

Kata Kunci: Lesson Study, Kompetensi Pedagogik, Calon Guru.

\section{PENDAHULUAN}

Fakta yang terjadi dalam dunia pendidikan saat ini sungguh sangat memprihatinkan diantaranya semakin rendahnya kesadaran dalam diri siswa untuk belajar khususnya mata pelajaran matematika. Dari hasil wawancara terhadap beberapa siswa dan guru ternyata banyak siswa yang takut dengan pelajaran matematika. Hal ini disebabkan karena mereka tidak senang dengan pelajaran matematika yang dianggapnya sulit, ada juga yang mengatakan bahwa proses pembelajarannya yang kurang menarik sehingga siswa yang tidak bisa semakin malas dengan matematika. Hal itu pun dibenarkan oleh beberapa guru matematika di sekolah tersebut yang mengatakan bahwa siswa-siswa sangat takut terhadap matematika, tetapi bukan berarti siswa-siswa tersebut tidak bisa jika proses pembelajarannya terstruktur dengan perencanaan. Lebih lanjut dikatakan bahwa ada juga guru yang mengajar seperti tidak mempersiapkan materi yang mau diajarkan, sehingga terkesan seadanya dalam mengajar.

Dalam Permendiknas Republik Indonesia No. 16 Tahun 2007 tentang standar kualifikasi akademik dan kompetensi guru yang salah satunya menyatakan tentang standar kompetensi pedagogik antara lain: 1) Menguasai karakteristik peserta didik dari aspek fisik, moral, spiritual, sosial, kultural, emosional, dan intelektual, 2) Menguasai teori belajar dan prinsipprinsip pembelajaran yang mendidik, 3) Mengembangkan kurikulum yang terkait dengan mata pelajaran yang diampu, 4) Menyelenggarakan pembelajaran yang mendidik, 5) Memanfaatkan teknologi informasi dan komunikasi untuk kepentingan pembelajaran, dll. 
Dalam penelitian ini standar kompetensi guru yang difokusnya untuk diteliti yaitu menyelenggarakan pembelajaran yang mendidik dengan salah satu kompetensinya yaitu memahami prinsip-prinsip perancangan pembelajaran yang mendidik, dan menyusun rancangan pembelajaran yang lengkap, baik untuk pembelajaran di dalam kelas, laboratorium maupun lapangan. Dari hal-hal tersebut yang mendorong untuk dilakukannya penelitian dengan menerapkan pembelajaran berbasis lesson study sebagai solusi masa depan proses pembelajaran. Lesson study sendiri awalnya berasal dari jepang yang siklusnya terdiri dari Plan, Do, See, seperti yang dijelaskan oleh Isoda, et.al. (2007), Fernandez and Yoshida (2004), Hart, et.al (2011), Dari sini akan dilihat apakah ada perbedaan antara perencanaan dan pelaksanaan pembelajaran berbasis lesson study dan yang tidak, serta bagaimana efek lesson study itu sendiri terhadap peningkatan kompetensi calon guru dan sejauh mana dampaknya terhadap kesiapan calon guru dalam mengajar.

Banyak penelitian yang fokus terhadap lesson study diantaranya Adams (2013), Copriady (2013), Jasmaniah, dkk (2013), Hunter dan Back (2011), Suhaili dan Khalid (2011), Isoda (2010), Chassels dan Melville (2009), dll yang semuanya mempunyai dampak yang positif terhadap proses pembelajaran. Adapun penelitian menurut Widoyoko dan Rinawati (2012) yang mengatakan bahwa kinerja guru sangat mempengaruhi motivasi siswa yang hasilnya juga dikatakan bahwa seorang guru yang mempunyai persiapan perencanaan dan strategi pembelajaran yang baik maka proses pembelajarannya pun akan semakin menarik motivasi siswa dalam pembelajaran. Penelitian ini tidak membahas tentang hasil belajar, namun proses perencanaan dan pelaksanaan pembelajaran disini lebih penting untuk mengasah kesiapan calon guru dalam melaksanakan tugas sebagai guru kedepannya. Selain itu, Isoda (2010) juga mengatakan dampak dari lesson study itu sendiri, yaitu ada pengingkatan yang signifikan terhadap pencapaian nilai matematika di sekolah dasar OZONE tempatnya meneliti.

\section{METODE PENELITIAN}

Jenis penelitian ini deskriptif kualitatif dengan jumlah calon guru ada 13 dengan lokasi penelitian di SMAN 1 Kota Gajah, Lampung Tengah. 13 calon guru tersebut terdiri dari berbagai program studi yaitu pendidikan matematika, pendidikan fisika, pendidikan biologi, pendidikan ekonomi, pendidikan bahasa inggris, dan pendidikan sejarah. Asumsi dalam penelitian ini adalah calon guru mempunyai kemampuan yang sama dalam berbagai aspek dan mendapat perlakuan yang sama pula.

Indikator yang digunakan untuk penguasaan perencanaan pembelajaran yaitu: 1) kelengkapan berkas perangkat pembelajaran, 2) Kualitas Rencana Program Pembelajaran (RPP), 3) Inovasi dalam merancang pembelajaran, 
dan 4) Kesiapan melaksanakan pembelajaran. Kemudian indikator pelaksanaannya yaitu 1) Menerapkan pembelajaran sesuai RPP yang sudah direncanakan, 2) Menguasai kelas, dan 3) Menguasai proses pembelajaran. Sedangkan untuk teknik pengumpulan data yang digunakan adalah observasi, dan wawancara. Obervasi digunakan untuk melihat calon guru dalam melakukan perencanaan dan pelaksanaan. Kemudian wawancara digunakan untuk mencocokkan hasil observasi yang telah dilakukan, sehingga data yang didapat benar-benar valid.

Rancangan penelitiannya yaitu memilih 4 sekolah yang akan dijadikan lokasi penelitian, kemudian menempatkan calon guru ke masingmasing sekolah dengan jumlah yang ditentukan sesuai kondisi sekolah tersebut. Selanjutnya calon guru melaksanakan perencanaan (membuat RPP) dan pelaksanaan sebanyak 6 kali dengan masing-masing 3 kali berbasis biasa (konvensional) dan 3 kali berbasis lesson study. Tiga pertemuan pertama perencanaan dan pelaksanaan pembelajarannya berbasis konvensional dan 3 pertemuan selanjutnya berbasis lesson study. Pada tahap yang menggunakan lesson study calon guru mengikuti langkah-langkah dalam lesson study yaitu ada tahap 1) Plan yaitu calon guru merancang pembelajaran dengan membuat RPP yang kemudian didiskusikan oleh beberapa guru dan teman sejawat, 2) $D o$ yaitu melaksanakan proses pembelajaran sesuai apa yang telah didiskusikan dalam plan, dan 3) See yaitu merefleksi proses pembelajaran yang telah berlangsung dan kemudian untuk diperbaiki pada proses pembelajarn selanjutnya. Sedangkan yang tidak menggunakan lesson study, calon guru hanya melakukan perencanaan sendiri yang kemudian dikoresi oleh 1 guru dan proses pembelajarannya hanya diamati oleh 1 guru pamong. Proses evaluasinya pun hanya dilakukan oleh guru pamong itu sendiri.

\section{HASIL PENELITIAN}

Dari penelitian yang telah dilakukan diperoleh hasil observasi pada perencanaan dan pelaksanaan pembelajaran yang berbasis biasa (konvensional) dan berbasis lesson study seperti yang terlihat pada Tabel 1 di bawah ini. Hasil tersebut adalah data kualitatif hasil observasi yang kemudian dikonversi ke dalam data kuantitatif. 
Tabel 1. Hasil Observasi Perencanaan dan Pelaksanaan Pembelajaran.

\begin{tabular}{|l|l|l|l|l|l|l|l|l|l|l|l|l|l|}
\hline \multirow{2}{*}{ No } & \multirow{9}{*}{$\begin{array}{c}\text { Nama } \\
\text { Calon Guru }\end{array}$} & \multicolumn{5}{|c|}{ Perencanaan } & \multicolumn{5}{c|}{ Pelaksanaan } \\
\cline { 3 - 16 } & & \multicolumn{3}{|c|}{ Konvensional } & \multicolumn{3}{|c|}{ Lesson Study } & \multicolumn{3}{|c|}{ Konvensional } & \multicolumn{2}{|c|}{ Lesson Study } \\
\hline 1 & Fitri Aljanah & 8,2 & 8,3 & 8,3 & 8,4 & 8,8 & 8,8 & 8,0 & 8,2 & 8,3 & 8,4 & 8,9 & 9,3 \\
\hline 2 & Tati Suryanti & 7,9 & 8,0 & 8,3 & 8,4 & 8,9 & 8,9 & 8,0 & 8,4 & 8,6 & 7,8 & 8,5 & 8,3 \\
\hline 3 & Rita Novita & 7,7 & 7,6 & 7,8 & 7,9 & 8,3 & 8,3 & 7,0 & 7,0 & 7,0 & 6,8 & 8,1 & 8,3 \\
\hline 4 & Heri Kurniadi & 7,9 & 8,1 & 8,2 & 8,2 & 8,7 & 8,8 & 8,5 & 8,6 & 9,0 & 8,6 & 9,3 & 9,9 \\
\hline 5 & Fevta Pratiwi & 8,2 & 8,2 & 8,3 & 8,4 & 9,0 & 9,1 & 9,0 & 9,2 & 9,3 & 8,9 & 9,6 & 10,0 \\
\hline 6 & Ari Maya & 7,7 & 7,7 & 7,9 & 7,8 & 8,4 & 8,7 & 7,8 & 8,2 & 8,3 & 8,4 & 9,5 & 9,8 \\
\hline 7 & Ferdy S. & 7,9 & 8,0 & 8,0 & 8,3 & 8,2 & 8,6 & 8,8 & 8,9 & 9,5 & 9,1 & 8,8 & 9,4 \\
\hline 8 & Anita Kurnia & 7,5 & 7,9 & 8,1 & 8,2 & 8,7 & 9,1 & 7,0 & 7,0 & 7,3 & 7,4 & 8,1 & 8,3 \\
\hline 9 & Wahyu Nur B. & 7,9 & 8,1 & 8,2 & 7,9 & 8,5 & 8,3 & 6,3 & 7,7 & 7,7 & 6,9 & 7,8 & 8,3 \\
\hline 10 & Astri Anggraini & 7,1 & 7,5 & 7,7 & 7,8 & 8,2 & 8,2 & 6,9 & 7,6 & 8,6 & 8,0 & 8,3 & 9,1 \\
\hline 11 & Tri Wulan I. & 7,0 & 7,3 & 7,2 & 7,7 & 8,2 & 8,3 & 7,3 & 8,5 & 7,7 & 7,9 & 8,8 & 8,9 \\
\hline 12 & Wulandari S. & 7,9 & 8,2 & 8,1 & 8,1 & 8,8 & 8,8 & 6,7 & 7,1 & 8,0 & 7,6 & 8,1 & 8,3 \\
\hline 13 & Mia Riawati & 8,2 & 8,3 & 8,3 & 8,4 & 8,8 & 8,8 & 8,3 & 8,3 & 8,4 & 6,5 & 9,0 & 9,9 \\
\hline
\end{tabular}

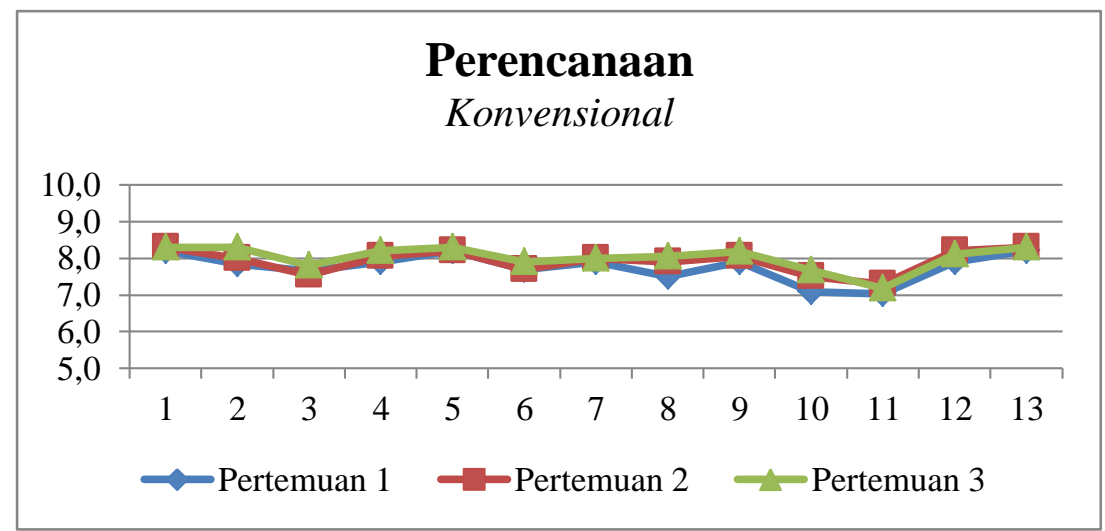

Gambar 1. Grafik Peningkatan pada Perencanaan Konvensional.

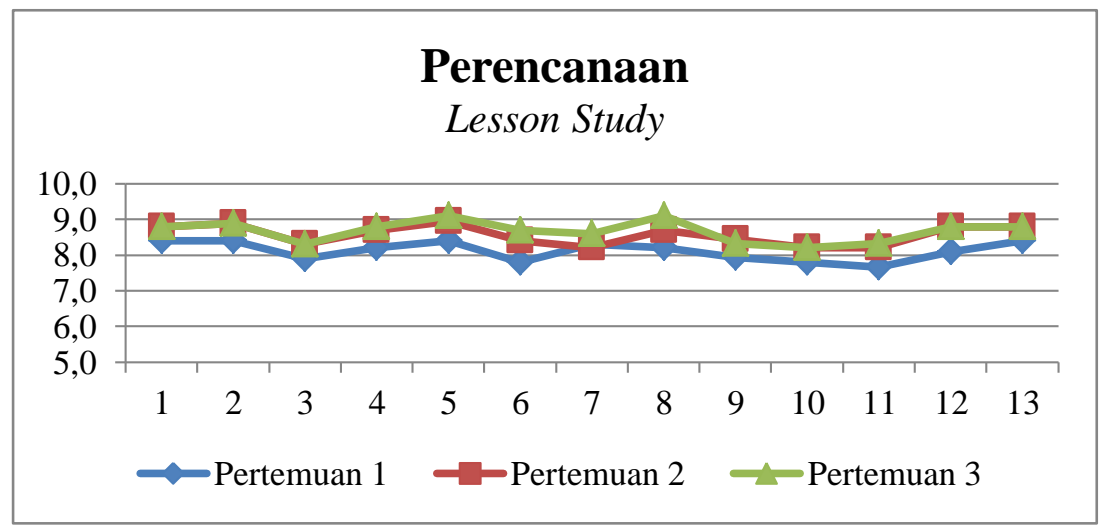

Gambar 2. Grafik Peningkatan pada Perencanaan Lesson Study. 


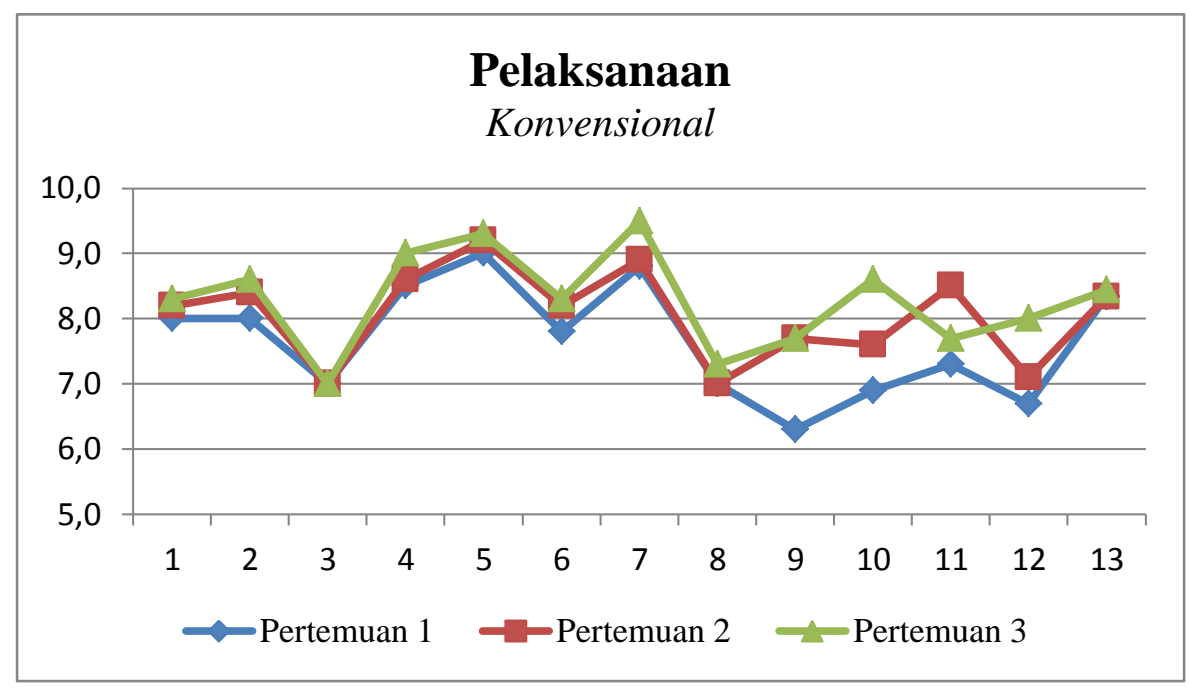

Gambar 3. Grafik Peningkatan pada Pelaksanaan Konvensional.

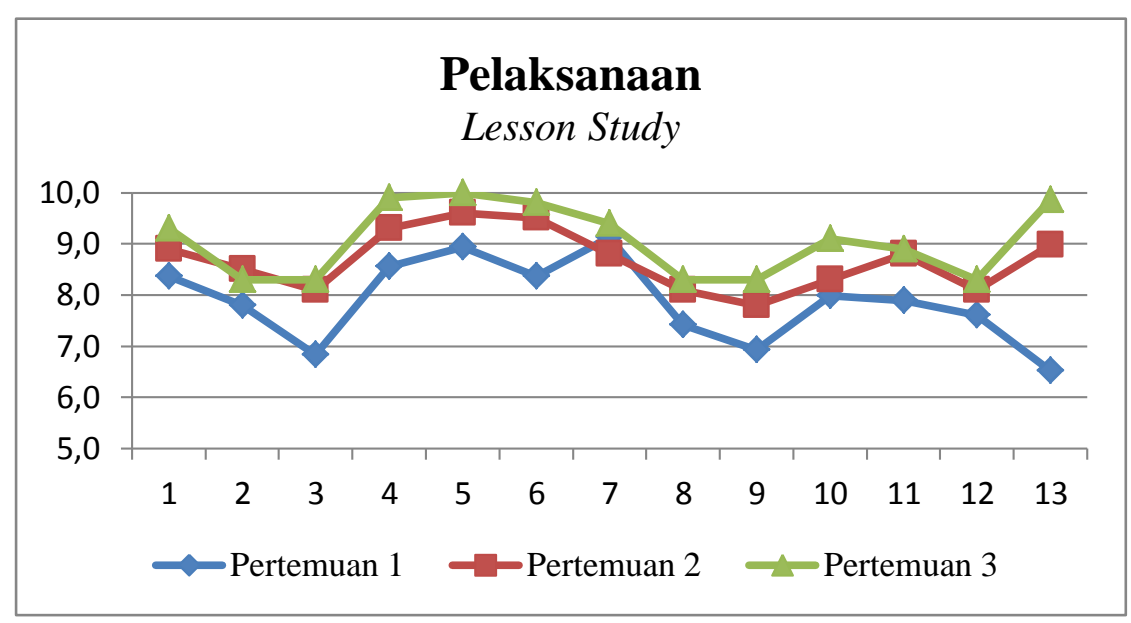

Gambar 4. Grafik Peningkatan pada Pelaksanaan Lesson Study.

Terlihat dari data tersebut bahwa proses perencanaan yang menggunakan lesson study peningkatannya cukup signifikan, berbeda dengan yang tidak menggunakan lesson study (konvensional) terlihat peningkatannya tidak begitu signifikan, bahkan cenderung konstan. Hal yang sama pun terjadi pada pelaksanaan pembelajaran, hasil yang ada dapat dilihat bahwa pelaksanaan berbasis lesson study peningkatannya pun cukup signifikan, sedangkan yang konvensional tidak begitu signifikan. Grafiknya pun dapat dilihat pada Gambar 1 - 4. Grafik tersebut di plot untuk setiap 3 kali 
pertemuan yang berbasis konvensional dan lesson study pada perencanaan dan pelaksanaan. Terlihat ada perbedaan peningkatan antara konvensional dan lesson study.

Sedangkan pada Tabel 2 di bawah ini adalah rata-rata dari hasil perencanaan dan pelaksanaan pembelajaran berbasis konvensional dan lesson study. Terlihat dari data ada perbedaan yang cukup signifikan.
Grafik perbandingannya pun dapat dilihat pada Gambar 5 dan 6, dari grafik tersebut terlihat jelas perbedaan rataratanya antara konvensional dan lesson study. Terlihat perencanaan dan pelaksanaan pembelajaran berbasis lesson study lebih baik hasilnya. Jika dilihat dari proses, maka yang berbasis lesson study lebih siap dan matang dalam memenuhi kompetensi pedagogik sebagai seorang guru.

Tabel 2. Rataan Perencanaan dan Pelaksanaan Pembelajaran konvensional dan Lesson Study.

\begin{tabular}{|l|l|c|c|c|c|}
\hline \multirow{2}{*}{ No } & \multirow{2}{*}{$\begin{array}{c}\text { Nama } \\
\text { Calon Guru }\end{array}$} & \multicolumn{2}{|c|}{$\begin{array}{c}c \\
\text { Perencanaan }\end{array}$} \\
\cline { 3 - 6 } & $\begin{array}{c}\text { Rataan } \\
\text { Konvensional }\end{array}$ & $\begin{array}{c}\text { Rataan } \\
\text { Lesson Study }\end{array}$ & $\begin{array}{c}\text { Rataan } \\
\text { Konvensional }\end{array}$ & $\begin{array}{c}\text { Rataan } \\
\text { Lesson Study }\end{array}$ \\
\hline 1 & Fitri Aljanah & 8,3 & 8,7 & 8,2 & 8,9 \\
\hline 2 & Tati Suryanti & 8,1 & 8,7 & 8,3 & 7,9 \\
\hline 3 & Rita Novita & 7,7 & 8,2 & 7,0 & 7,7 \\
\hline 4 & Heri Kurniadi & 8,1 & 8,6 & 8,7 & 9,3 \\
\hline 5 & Fevta Pratiwi & 8,2 & 8,8 & 9,2 & 9,5 \\
\hline 6 & Ari Maya & 7,8 & 8,3 & 8,1 & 9,2 \\
\hline 7 & Ferdy S. & 8,0 & 8,4 & 9,1 & 9,1 \\
\hline 8 & Anita Kurnia & 7,8 & 8,7 & 7,1 & 7,9 \\
\hline 9 & Wahyu Nur B. & 8,0 & 8,2 & 7,2 & 7,7 \\
\hline 10 & Astri Anggraini & 7,4 & 8,1 & 7,7 & 8,5 \\
\hline 11 & Tri Wulan I. & 7,2 & 8,1 & 7,8 & 8,5 \\
\hline 12 & Wulandari S. & 8,1 & 8,6 & 7,3 & 8,0 \\
\hline 13 & Mia Riawati & 8,3 & 8,7 & 8,4 & 8,5 \\
\hline
\end{tabular}




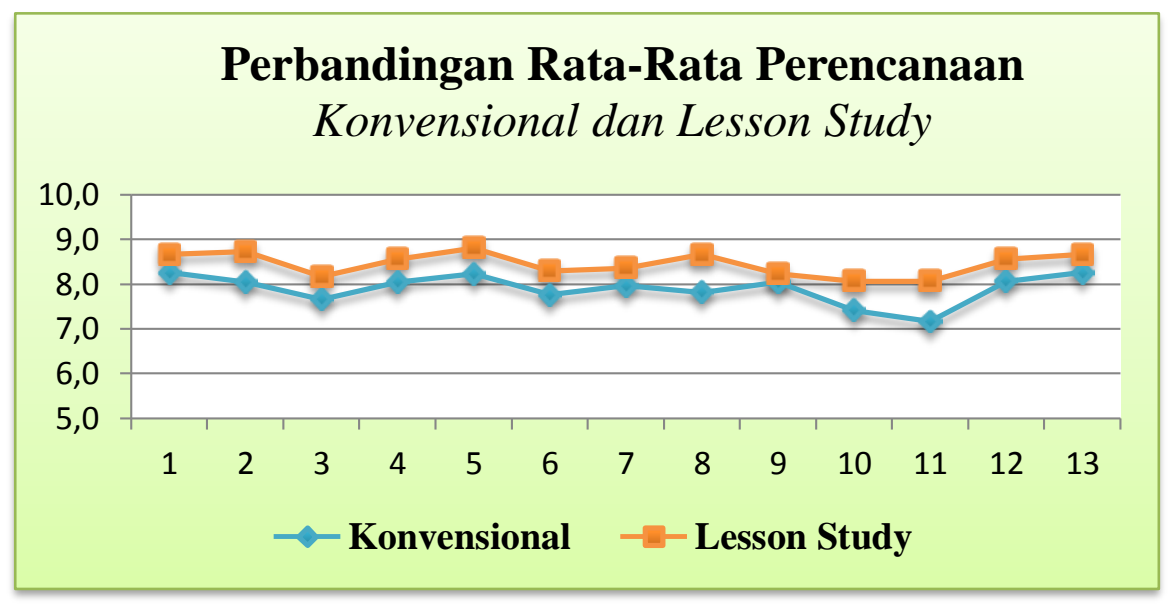

Gambar 5. Grafik Perbandingan Rata-rata Perencanaan Konvensional dan Lesson Study.

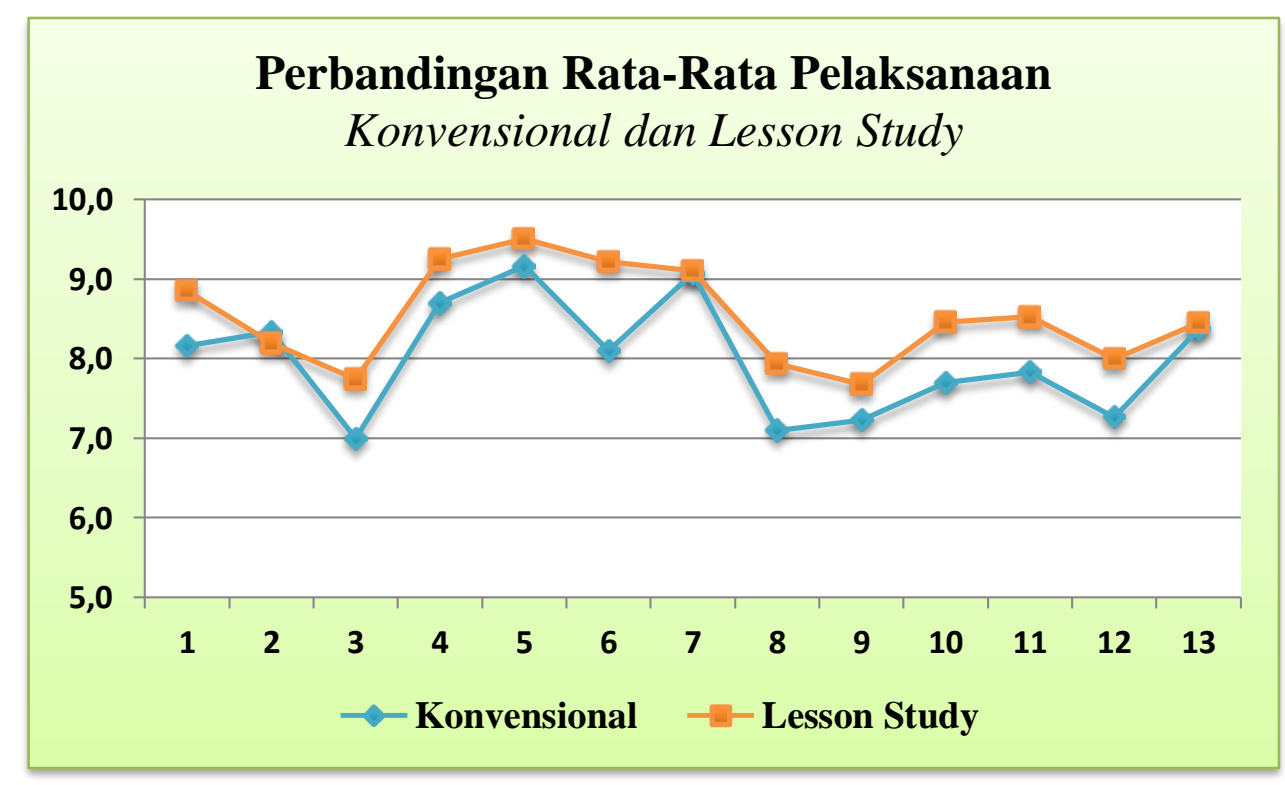

Gambar 6. Grafik Perbandingan Rata-rata Pelaksanaan Konvensional dan Lesson Study. 


\section{PEMBAHASAN}

Dari hasil di atas terlihat jelas bahwa perencanaan dan pelaksanaan pembelajaran berbasis lesson study lebih baik dibandingan yang konvensional, terlihat dari grafik perencanaan maupun pelaksanaan pada Gambar 1-6. Hasil tersebut merupakan data hasil konversi dari hasil observasi. Kemudian efek lesson study sendiri terhadap peningkatan kompetensi pedagogik calon guru sangat positif, dimana dengan menerapkan perencanaan dan pembelajaran berbasis lesson study, calon guru lebih siap dalam memenuhi standar kompetensi pedagogiknya. Semua indikator yang diamati baik pada saat perencanaan maupun pelaksanaan, yang berbasis lesson study jauh lebih baik. Dampaknya pun yang dialami oleh calon guru dalam mengajar terlihat lebih siap dan lebih baik. Hal ini tentunya bukan hanya berorientasi pada hasil, namun seorang calon guru dituntut harus tahu dan paham terhadap tugasnya sebagai guru kelak. Proses pembelajaran harus dirancang dan didiskusikan bersama-sama sehingga akan jauh lebih baik. Dengan begitu, dampak dari persiapan yang baik, hasilnya pun akan baik.
Dari hasil observasi diperoleh informasi bahwa pada tahap perencanaan, baik berbasis konvensional maupun lesson study semuanya memenuhi indikator yang pertama, yaitu kelengkapan berkas perangkat pembelajaran. Indikator kedua yaitu kualitas RPP, dimana kualitas RPP yang berbasis lesson study memiliki kualitas yang jauh lebih baik karena pada saat plan prosesnya dibahas bersama-sama oleh ahli, guru, maupun teman sejawat, sehingga banyak saran dan ide yang membangun. Hal itu mungkin tidak didapatkan pada perencanaan berbasis konvensional karena pengerjaannya pun sendiri dan saran hanya dari guru yang komentarnya pun hanya sebatas teknis.

Selanjutnya pada indikator yang ketiga, yaitu inovasi merancang pembelajaran, dimana proses perancangan pembelajaran berbasis lesson study lebih memiliki inovasi, contohnya dalam menentukan metode ataupun strategi pembelajaran, memilih media yang tepat, maupun desain pembelajarannya. Namun perencanaan konvensional terlihat kurang berinovasi karena calon guru menganggap apa yang dirancang sudah baik, padahal belum tentu. Indikator yang terakhir 
dalam perencanaan yaitu kesiapan melaksanakan pembelajaran, dimana yang berbasis lesson study juga lebih baik karena proses perencanaannya calon guru harus memaparkannya dahulu, sehingga apa yang mau diajarkannya terlihat sudah paham.

Indikator pelaksanaan yang pertama yaitu menerapkan pembelajaran sesuai RPP yang sudah direncanakan, dimana calon guru yang pembelajarannya berbasis lesson study semuanya melaksanakan pembelajaran sesuai dengan RPP, sedangkan yang berbasis konvensional ada 3 calon guru yang tidak sesuai dengan RPP. Indikator kedua yaitu menguasai kelas, dimana calon guru yang pembelajarannya berbasis lesson study semuanya menguasai kelas karena persiapannya sangat baik. Berbeda hal dengan yang berbasis konvensional, walaupun semuanya menguasai kelas namun tingkat penguasaannya jauh lebih rendah dibandingkan yang lesson study. Ketika diwawancara ternyata calon guru yang tidak dipantau penguasaan kelasnya cenderung sama.sedangkan yang berbasis lesson study selalu meningkat disetiap pertemuan. Indikator terakhir yaitu menguasai proses pembelajaran, dimana hasilnya hampir sama pada indikator kedua dimana proses pembelajaran yang berbasis lesson study terlihat lebih baik dan lebih menarik, sehingga peserta didik pun terlihat antusias.

\section{KESIMPULAN}

Dari penelitian ini dapat disimpulkan bahwa lesson study sangat baik untuk diterapkan sehingga proses pembelajaran menjadi lebih baik. Lesson study mengajarkan untuk lebih merancang pembelajaran secara terstruktur, meningkatkan kreativitas dan inovasi dalam merancang pembelajaran, serta menjadikan seorang guru memiliki kompetensi yang baik. Kesimpulan dari penelitian ini adalah perencanaan dan pelaksanaan berbasis lesson study lebih baik dibandingkan yang berbasis konvensional. Selanjutnya, efek dari lesson study itu sendiri dapat mengembangkan kompetensi pedagogik bagi calon guru. Ketiga, dampak dari lesson study terlihat bahwa calon guru lebih siap dan baik dalam melaksanakan pembelajaran. Kesimpulan terakhir yaitu lesson study sangat disarankan untuk proses pembelajaran yang lebih baik. 


\section{UCAPAN TERIMA KASIH}

Penulis mengucapkan terima

kasih yang sebesar-besarnya kepada

Rektor, Dekan FKIP, serta rekan-rekan

Dosen $\quad$ FKIP Universitas

Muhammadiyah Metro yang telah membantu menyusun penelitian ini. Terima kasih juga yang sebesarbesarnya untuk dana penelitian yang diberikan oleh UPT PPL FKIP Universitas Muhammadiyah Metro. Penulis ucapkan terima kasih juga untuk semua mahasiswa yang telah membantu dalam penelitian ini dan juga untuk SMAN 1 Kota Gajah.

\section{DAFTAR PUSTAKA}

Adams, J.W. 2013. A Case Study: Using Lesson Study To Understand Factors That Affect Teaching Creative And Critical Thinking In The Elementary Classroom. Doctoral Dissertation. Drexel University. [Online]

$\underline{\text { http://idea.library.drexel.edu/bits }}$ tream/1860/4131/1/Adams_Jane tEdD.pdf

diakses 3 Februari 2014.

Chassels, C. dan Melville, W. 2009. Collaborative, Reflective, and Iterative Japanese Lesson Study in an Initial Teacher Education Program: Benefits and
Challenges. Canadian Journal of Education 32, 4 (2009):734763

Copriady, J. 2013. The Implementation of Lesson Study Programme for Developing Professionalism in Teaching Profession. Journal of Asian Social Science, Vol. 9 No. 12. P.176-186

Fernandez, C., and Yoshida, M. (2004). Lesson study: A Japanese approach to improving mathematics teaching and learning. Mahwah, NJ: Lawrence Erlbaum Associates.

Hart, L.C., Alston, A.S., and Murata, A. (Ed.). 2011. Lesson Study Research and Practice in Mathematics Education. Springer: New York.

Hunter, J. and Back, J. 2011. Facilitating Sustainable Professional Development through Lesson Study. Mathematics Teacher Education and Development. Vol. 13.1 94114

Isoda, M., Stephens, M., Ohara, Y., \& Miyakawa, T. (2007). Japanese Lesson Study in Mathematics Its impact, diversity and potential for educational improvement. Singapore: World Scientifics Publishing Co. Pte. Ltd. 
Isoda, M. 2010. Lesson Study: Problem Solving Approaches in Mathematics Education as a Japanese Experience. Procedia Social and Behavioral Sciences: ICMER 2010. Elsevier.

Jasmaniah, Karim, A., and Zulkifli. $2013 . \quad$ Implementation Pembelajaran Bilangan dan Operasinya Melalui Lesson Study. Jurnal Pendidikan Almuslim Vol.1 No.1.

Permendiknas. 2007. Standar Kualifikasi Akademik dan Kompetensi Guru. Menteri Pendidikan Nasional. No.16 Tahun 2007.

Suhaili, A.S.B. dan Khalid, M. 2011. Mathematics Teachers' Perception of Lesson Study as a Continuous Professional Development Programme. Journal of Science and Mathematics. Education in Southeast Asia. Vol.34 No.1. p.67-89

Widoyoko, S.E.P. dan Rinawati, A. 2012. Pengaruh Kinerja Guru terhadap Motivasi Siswa. UNY. Jurnal Cakrawala Pendidikan: th XXXI No.2. 